\title{
Effect of different transportation period on body weight loss, hematological and biochemical stress responses of sheep
}

\author{
L. Lendrawati ${ }^{1,2}$, R. Priyanto ${ }^{3, *}$, A. Jayanegara ${ }^{4}$,W. Manalu ${ }^{5}$ and D. Desrial ${ }^{6}$ \\ ${ }^{1}$ Department of Animal Production and Technology, Faculty of Animal Science, \\ Andalas University, Kampus Limau Manis, Padang 25163 - Indonea \\ ${ }^{2}$ Graduate School of Animal Production and Technology, Faculty of Animal Science, \\ IPB University, Dramaga Campus, Bogor 16680 - Indonesia \\ ${ }^{3}$ Department of Animal Production and Technology, Faculty of Animal Science, \\ IPB University, Dramaga Campus, Bogor 16680 - Indonesia \\ ${ }^{4}$ Department of Nutrition and Feed Technology, Faculty of Animal Science, \\ IPB University, Dramaga Campus, Bogor 16680 - Indonesia \\ ${ }^{5}$ Department of Anatomy, Physiology and Pharmacology, Faculty of Veterinary Medicine, \\ IPB University, Dramaga Campus, Bogor 16680 - Indonesia \\ ${ }^{6}$ Department of Mechanical Engineering and Biosystem, Faculty of Agricultural Technology, \\ IPB University, Dramaga Campus, Bogor 16680 - Indonesia \\ *Corresponding E-mail: rudypriyanto@gmail.com
}

Received December 29, 2019; Accepted April 30, 2020

\begin{abstract}
ABSTRAK
Penelitian ini bertujuan untuk mengevaluasi pengaruh durasi transportasi selama 4, 8 dan 12 jam terhadap penurunan bobot badan, profil hematologi dan biokimia darah domba. Sebanyak 24 ekor domba ekor tipis jantan didistribusikan terhadap enam kelompok perlakuan yaitu: kelompok transportasi selama 4, 8 dan 12 jam (T4, T8 dan T12) dan kelompok non-transportasi selama 4, 8 dan 12 jam (NT4, NT8 dan NT12), masing-masing perlakuan terdiri dari 4 ekor domba. Semua domba perlakuan diangkut dengan sebuah mobil pick up dengan tingkat kepadatan $0,28 \mathrm{~m}^{2} /$ ekor sesuai dengan perlakuan. Parameter yang diukur adalah penyusutan bobot badan, profil hematologi dan biokimia darah. Hasil penelitian menunjukkan bahwa peningkatan durasi transportasi nyata menurunkan $(\mathrm{P}<0,05)$ bobot badan dan meningkatkan $(\mathrm{P}<0,05)$ kadar hematokrit, kortisol, serta glukosa darah. Namun demikian, nilai-nilai tersebut masih berada dalam kisaran normal pada domba. Dapat disimpulkan bahwa domba ekor tipis yang sehat dapat mentolerir efek buruk transportasi sampai 12 jam perjalanan.
\end{abstract}

Kata Kunci: transportasi, domba, bobot badan, hematologi, biokimia darah

\begin{abstract}
The study was conducted to evaluate the duration of road transportation during 4, 8 and 12 hours on body weight loss, hematological and biochemical responses of sheep. Twenty-four male Javanese thin tailed sheep were separated into transported group (T4, T8 and T12) and non-transported group (NT4, NT8 and NT12). Transportation (T) groups were transported for 4, 8 and $12 \mathrm{~h}$ in the same open pick up with $0.28 \mathrm{~m}^{2} /$ head of loading density. Body weight, haematological and biochemical blood profiles were determined. The results showed that increasing of transportation duration significantly increased $(\mathrm{P}<0.05)$ body weight loss and decreased $(\mathrm{P}<0.05)$ hematocrit, cortisol and glucose values in
\end{abstract}


the blood. However, these values were in the normal range of sheep well-being. In conclusion, transported healthy Javanese thin tailed sheep under good condition without feed and water access up to $12 \mathrm{~h}$ can tolerate to adverse effect of transportation without disturbing their welfare.

Keywords: : transportation, sheep, body weight, haematological, biochemical

\section{INTRODUCTION}

Unavoidable transportation as a supporting factor in the livestock business is known as one of the common cause of stress. An animal will be experienced of transportation at least once in their lifetime for one of the purposes of selling, slaughtering, fattening or breeding in sheep production systems (Zhong et al., 2011). The handling, uploading, fasting, confinement, vibration, downloading, changing light condition, poor air quality and mixing of unfamiliar group are kinds of potentials stressors during transport that may cause of physiological stress and behavior changes in sheep (Grandin, 1997; Cockram et al., 2000; Saeb et al., 2010; Samimi et al., 2018). Moreover, Maria et al. (2003) and Adzitey (2011) reported that duration and distance, loading density, weather and road condition can be listed as some stressors in livestock during transport. Stressed transport has a great effect on animal performance, increased of body weight loss, morbidity and mortality and decreased meat quality, and consequently, may cause considerable economic loses (Ayo and Oladele,1996; Swanson and Morrow, 2001; Fazio and Ferlazzo, 2003). Due to both economic and animal welfare problems, stress during transport has become a big concern in a few decades.

Though, until this time there is no uniform limits on duration of transportation for sheep in some countries. European Union and some developed countries have legislated and limited transportation in animals not more than $8 \mathrm{~h}$ without access to water and feed during transportation (European Council, 2005). Increasing the duration of transportation may affect animal welfare through fatigue, dehydration, and metabolic disorders as a result of stress during transportation. However, some previous studies reported that road transportation for $3,9,15,18$ and $24 \mathrm{~h}$ did not indicate dehydrated or metabolic compromised in $38 \mathrm{~kg}$ sheep (Knowles et al., 1995), as well as Fisher et al. (2010) that transported sheep for 12, 30 and 48 h. In addition, Cole (1995) concluded that untransported sheep with a good condition can tolerate to feed and water withdrawal for 3 days.
The physiological stress during road transportation can be shown in concentration of blood constituents, such as cortisol, glucose, plasma urea and creatine kinase (Krawczel et al., 2007; Fisher et al., 2010). Previous studies that focused on the adverse effects of transportation in sheep with duration 24, 48 and $72 \mathrm{~h}$ (Horton et al., 1996; Knowles et al., 1996; Fisher et al., 2010) were conducted in temperate regions and, to the best of our knowledge, there have been lack of studies that reported transportation effects on sheep under hot-humid tropical region. Transporting animal in tropical region with high temperature and relative humidity has been more challenging than that in temperate region (Minka and Ayo, 2012). Therefore, this study was conducted to evaluate effect differing transportation and starvation period on body weight loss and physiological responses of Javanese thick tailed sheep.

\section{MATERIALS AND METHODS}

\section{Experimental Animals}

This study used 32 healthy Javanese thick tailed male sheep aged 10-12 months and 22-24 $\mathrm{kg}$ live weight, in which 24 sheep were used for treatments and 8 sheep served as filler. All sheep were fed with concentrate completed feed and originated from the similar farm, located in Bogor, Indonesia.

\section{Procedure}

Two days before the study, 32 sheep were selected and housed in a separate pen on the farm. Sheep were grouped and marked with different colours to distinguish all of the treatments approximately $12 \mathrm{~h}$ before the beginning of transportation. Treatments were arranged in a factorial design in which the first factor was transportation (transport [T] and non-transport $[\mathrm{NT}])$ and the second factor was duration $(4,8$ and $12 \mathrm{~h}$ ). In total there were six treatment combinations, i.e., T4, T8, T12, NT4, NT8 and NT12.

Both of transported and non-transported sheep were individually weighed before transportation. All three duration groups in the 
transported trial were loaded into open pick-up (Suzuki Mega Carry, made in Japan) with a $2.4 \mathrm{~m}$ long $\times 1.6 \mathrm{~m}$ wide $\times 1.2 \mathrm{~m}$ tall compartment, whereas non-tranported stayed at same colony cage. The sheep were transported for 4,8 and $12 \mathrm{~h}$ from 04.00 to $16.00 \mathrm{AM}$ without access to feed and drinking water during transportation. Air temperature $\left({ }^{\circ} \mathrm{C}\right)$ and humidity $(\%)$ were recorded during the study using Digital Thermo Hygrometer HTC-1 (Taiwan) which placed in the vehicle and colony cage.

Road transportation occurred mainly on public highways with average speed about 40 $\mathrm{km} /$ hour. The T4 sheep were unloaded after $4 \mathrm{~h}$ of road transport, and at the same time NT4 sheep were weighed and blood samples were collected. Further, four fillers sheep were loaded on to the vehicle to keep balance of density before the journey for another $8 \mathrm{~h}$. Similarly, T8, NT8, T12 and NT12 sheep were weighed and collected of blood samples immediately after unloaded.

Blood samples $(6 \mathrm{ml})$ from each animal were collected via jugular venipuncture and decanted into two sterile tubes. An amount of $4 \mathrm{ml}$ blood was tranferred into one tube without anticoagulant for serum collection for biochemical measurements. The remaining $2 \mathrm{ml}$ blood was put into another tube with $0.14 \%$ anticoagulant (EDTA K3, Onemed Healthy Care, Australia) to determine hematological parameters. The tubes were immediately placed in a box ice and taken to the laboratory for analysis.

Whole blood was used to determine red blood cell (RBC), hemoglobin, hematocrit, mean capsular hemoglobin $(\mathrm{MCH})$, mean capsular volume (MCV), mean capsular hemoglobin concentration (MCHC), white blood cell (WBC), neutrophil $(\mathrm{N})$, lymphocyte $(\mathrm{L})$, monocyte and $\mathrm{N} / \mathrm{L}$ ratio using an automatic blood analyzer (American Abaxis Vetscan HM5). Whereas, the serum was used to determine total protein (TP), albumin, globulin, aspartate transaminase (AST), alkaline phosphatase (ALP), creatine kinase (CK), blood urea nitrogen (BUN), glucose, calcium, phosphorus and magnesium concentration using an automatic biochemical analyzer (American Abaxis Vetscan VS2). The serum of cortisol value was analyzed using enzyme linked immuno sorbent assay (ELISA) method (DRG Diagnostics $\mathrm{GmbH}$, Germany).

\section{Statistical Analysis}

Randomized block design with two factors was used in this study. The first factor was transportation (transported and non-transported) and the second factor was duration $(4,8$ and 12 h). Data were analyzed by using analysis of variance with Duncan Multiple Range Test for the post-hoc test. The statistical analysis was performed by using SPSS software version 25.0.

\section{RESULTS}

The mean of temperature and relative humadity on the vehicle during journey were $25.20 \pm 1.98^{\circ} \mathrm{C}$ and $72.50 \pm 17.46 \%$, respectively. While these values at the farm during study period were $28.2 \pm 4.57^{\circ} \mathrm{C}$ and $77.9 \pm 16.2 \%$, respectively. The average of THI during transportation was $74.1 \pm 2.03$ (max. 77.0, min. 70.6) and at the experimental farm was $78.2 \pm 4.99$ (max. 82.7, min. 70.2).

The mean of body weight loss and haematological profile of sheep are presented in Table 1. Increasing transportation and starvation duration of sheep caused a significant increase in body weight loss, hematocrite, neutrophil percentage and decrease in lymphocite percentage $(\mathrm{P}<0.05)$. Transportation and starvation of sheep for $12 \mathrm{~h}$ increased body weight loss on arrival compared with for 4 and $8 \mathrm{~h}(\mathrm{P}<0.05)$.

No difference was found between the 4 and 8 $\mathrm{h}$ treatments in the body weight loss. Regarding the haematological values, RBC and hemoglobin tended to increase during 4,8 and $12 \mathrm{~h}$ transportation, but there was no significant in $\mathrm{RBC}$ and hemoglobin between 4, 8 and $12 \mathrm{~h}$ duration both of transportation and nontransportation treatments. Hematocrite followed the same trend as RBC and hemoglobin, i.e., increased after 8 and $12 \mathrm{~h}$ transportation. Transported treatment had higher level of RBC, hemoglobin and hematocrite than drink and water deprivated. $\mathrm{MCH}, \mathrm{MCV}, \mathrm{MCHC}$ and monocyte level were not different between treatments. WBC, percentage of neutrophil and ratio N/L also increased significantly while percentage of lymphosyte decresed $(\mathrm{P}<0.05)$ after 4,8 and $12 \mathrm{~h}$ transportation. No differences between before and $4 \mathrm{~h}$ were found for hematocrite $\mathrm{WBC}$ and ratio $\mathrm{N} / \mathrm{L}$ both of transport and starvation experiment, similarly with 8 and $12 \mathrm{~h}$ duration. Duration of transportation and starvation treatment significantly affected $(\mathrm{P}<0.05)$ in haematological respon of sheep, however transport and non transported treatment showed almost similar effects. 


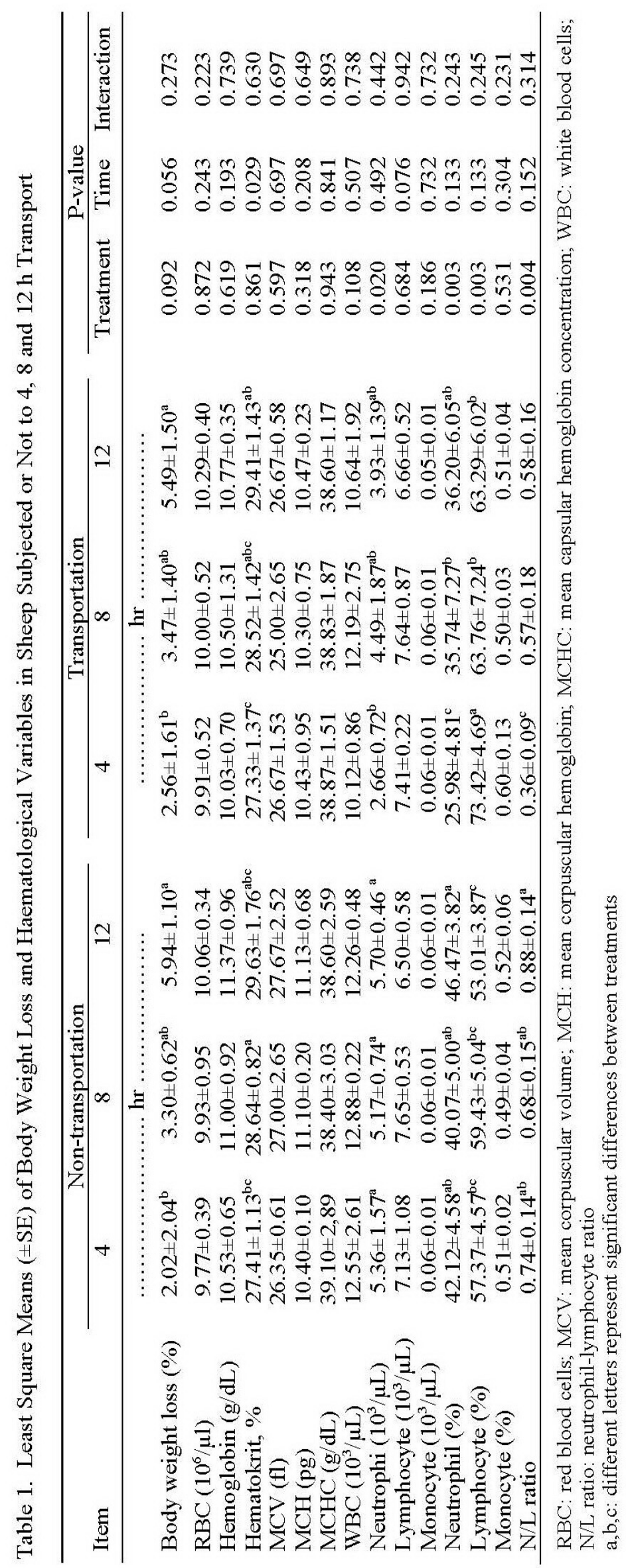


Transported sheep had higher cortisol levels than non-transported after 4,8 and $12 \mathrm{~h}$ transportation (Table 2). Transportation during $8 \mathrm{~h}$ had higher of cortisol value than $4 \mathrm{~h}$ and $12 \mathrm{~h}$, while transport during $4 \mathrm{~h}$ and $12 \mathrm{~h}$ showed almost similar in cortisol $(28.50 \pm 2.79$ and $26.53 \pm 2.97 \mathrm{ng} / \mathrm{ml}$ ). Cortisol level remaind constant in non-transport treatment during 4, 8 and $12 \mathrm{~h}$. Glucose, AST and creatine kinase followed the same trend of cortisol, i.e., increased significantly after 4,8 and $12 \mathrm{~h}$ of transportation $(\mathrm{P}<0.05)$. Albumin, globulin, ALP and BUN values were similar between transported and nontransported treatments during 4, 8 and $12 \mathrm{~h}$. Calcium, phosphorus and magnesium were quite consistent both for transported and nontransported groups.

\section{DISCUSSION}

The main results in the current study were that increase transportation and starvation duration on Javanese thick tailed resulted in increasing of body weight loss, hematocrite, percentage of neutrophil, $\mathrm{N} / \mathrm{L}$ ratio, cortisol, glucose, total protein, but clinically these effect for any duration fell within normal ranges. The new information from this study would suggest that transportation and starvation of sheep under hot-humid tropical environment until $12 \mathrm{~h}$ did not disturb animal health. Sheep showed more stress and dehydration after $8 \mathrm{~h}$ transport or starvation that caused by higher temperature and humadity during transport or on the farm. Villarroel et al. (2011) reported that suddenly changing in temperature and humidity during road transport can affect animal welfare. Furthermore, Silanikove (2000) stated that THI as used to determine condition of environment can effect heat stress in animal: $\leq 74$, comfort; $75-78$, alert stress; 79-83, excess stress; $\geq 84$, emergency.

In our result, THI values fell within the alert category for transport and almost danger for starvation on the farm treatment. Heat stress and dehydration as an effect of high temperature can stimulate evaporative heat loss by panting and sweating in the animal (Caufield et al., 2014). Similar to Miranda-de la Lama et al. (2011) also found that temperature and humadity rise quickly in the truck after loading. In contrast in this study temperature during transport lower than temperature on farm during 4,8 and $12 \mathrm{~h}$ period (25.20 and $28.20^{\circ} \mathrm{C}$ ).

Body weight loss during transportation as a result of metabolic and dehydration disorders associated with animal welfare greatly affects livestock production (Fisher et al., 2010). The magnitude of body weight lost in the present study was $2.56,3.4,5.49 \%$ and $2.02,3.30,5.94 \%$ for the 4,8 and $12 \mathrm{~h}$ transport and starvation respectively. There was no diffrences in body weight loss between transported and starvation sheep in this study may caused by both of treatment deprived of feed and water for 4, 8 and 12 h. Knowles (1998) also stated that decreasing body weight of animal depend on duration of animals suffering from lack of food and water.

Body weight loss in our result lower than studied by Zhong et al. (2011) that during $8 \mathrm{~h}$ of road transportation of Ujumqin sheep may lose $9.04 \%$ of body weight. Furthermore, Knowles et al. (1995) recorded that transport of sheep with body weight $38 \mathrm{~kg}$ during $3,9,15,18$ and $24 \mathrm{~h}$ in temperature of environment below of $20^{\circ} \mathrm{C}$ were adapted to the journey and clinically not suffered for dehydration or metabolic disorder. Moreover, Cole (1995) also reported that healthy untransported sheep tolerated with food and water deprivation for 3 day, similarly in transported sheep under good conditions (Knowles et al., 1996).

White blood cell commonly has been used to access animal health. Paul et al. (2008) reported that rising cortisol levels as stressors response in animals affected haematological, increase in neutrophil counts and decrease in lymphocytes. However, our current study found that the number of neutrophil, lymphocyte and neutrophil : lymphocyte ratio were not influenced by transportation only but also by starvation. This result agreed with Fisher et al. (2010) that $\mathrm{N}: \mathrm{L}$ ratio increased after 12,30 and $48 \mathrm{~h}$ transport.

A significant increase in neutrophil, in the $\mathrm{N} / \mathrm{L}$ ratio and decrease lymphocyte was found during 4,8 and $12 \mathrm{~h}$ both of transportation and starvation treatment. Non transported trial showed greater N/L ratio than transported sheep. The reason for this result might be due to non transport treatment that keep on farm heat stress as a result of increasing of ambient temperature, consequently for this result not transported sheep more stressed than transported trial.

Increasing of total protein, albumin and hematocrit usually are used as hydration indicator in animal. In our case, only hematocrit were increased significantly as an effect of transportation and starvation during 4,8 and $12 \mathrm{~h}$ periods. Hematocrit on transported and starvation 


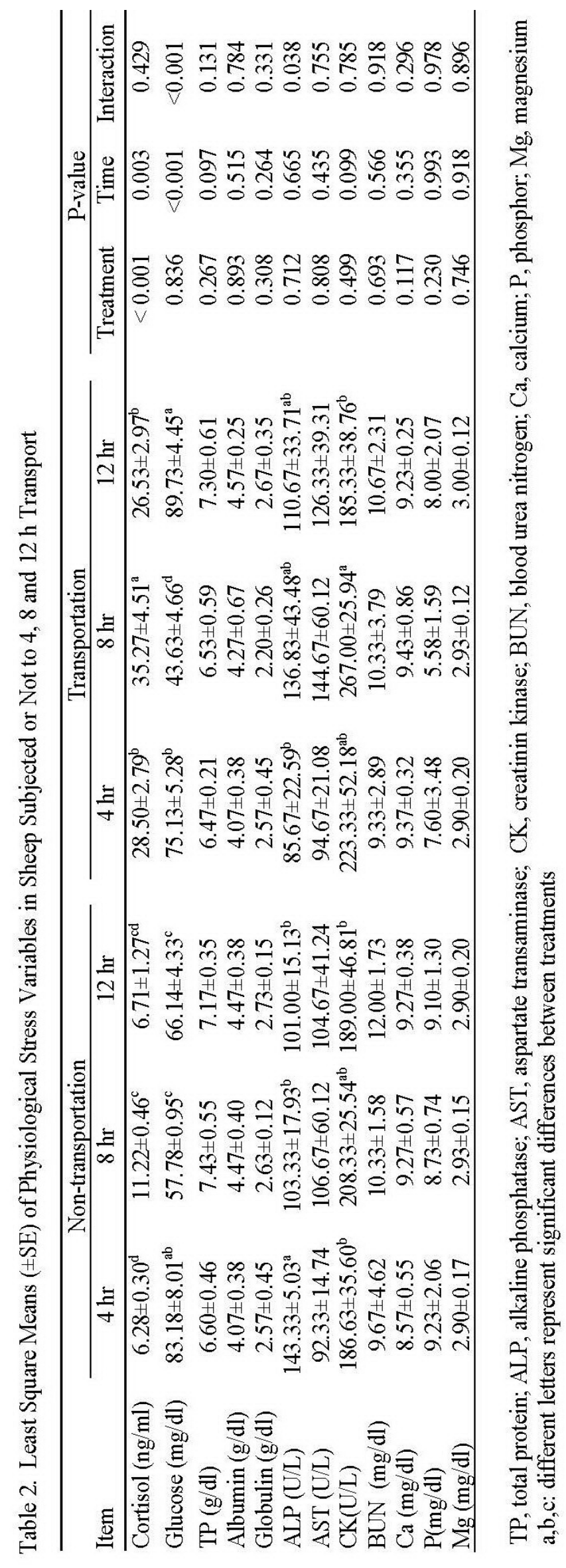


for 8 and $12 \mathrm{~h}$ generally being greater than $4 \mathrm{~h}$ periods. However, these levels clinically did not exceed the normal limits that recognized for sheep.

Cortisol commonly is used to determine physiological stress response of the transported sheep (Krawezel et al., 2007). Previous studies showed that cortisol level tend to increase during and following transported sheep (Ekiz et al., 2013). In addition, serum cortisol level in transport sheep increases at the beginning, post loading and back to basal level after few hours of journey (Broom et al., 1996; Cockram et al., 1997). In our case, cortisol reached the peak after $8 \mathrm{~h}$ transport $(35.27 \mathrm{ng} / \mathrm{dl})$, while after $12 \mathrm{~h}$ transport cortisol level similar with after $4 \mathrm{~h}$ transport (26.53 and $28.50 \mathrm{ng} / \mathrm{dl})$. Consistent with Pascual-Alonso et al. (2016) reported that cortisol levels were twice the pre-transport after $4 \mathrm{~h}$ transport and two times greater than coltrol. The results of glucose are consistent with the measured cortisol levels.

Our results showed that serum glucose was influenced by interaction between treatment and length transport of the sheep. Glucose serum in transport group increased in $4 \mathrm{~h}$ period, decreased in $8 \mathrm{~h}$, and increased after $12 \mathrm{~h}$ transport; however, this variable did not change in non transport sheep for any duration. Higher serum glucose is an indicator of metabolic response to stress in animals (Moberg, 1985; Ali et al., 2006). Moreover, Knowles et al. (1995) stated that increasing plasma glucose because of response to initial stress and it will be decrease for up to $24 \mathrm{~h}$ as a metabolic exhaustion marker. Miranda-de la Lama et al. (2012) have shown that increasing of glucose during stress is started by an increasement of cortisol levels as an effect gluconeogenic.

In contrast with current study, greater glucose concentration was found after $12 \mathrm{~h}$ transport, while the greater cortisol level was showed after $8 \mathrm{~h}$ transport. The reason for this may be that transport during $8 \mathrm{~h}$ more stressed for the sheep because their start to expose heat stress as a result of increasing of temperature. Moreover, glucose reserves begin to run out after $8 \mathrm{~h}$ of transportation and energy needs obtained from the breakdown of body fat and protein, so that glucose levels rise again after 12 transportation. This phenomenon was supported by blood urea nitrogen levels that greater after $12 \mathrm{~h}$ of transportation. Some studies agree with our explanations that rising blood urea nitrogen (BUN) during transport indicated that limited glucose reserves, therefore body fat and protein have to break down to obtain energy during stress condition (Fisher et al., 2010).

Transport and starvation trial have similar effect in blood urea nitrogen concentration, that tend to increase with increasing duration of trial. Transport for 4,8 and $12 \mathrm{~h}$ duration in this study were not seriously stressed for Javanese thick tailed, but deprivation of feed and water caused changing in some blood metabolites, like BUN, total protein and glucose concentration. These changes could be affected to food deprivation, more pronounced in $12 \mathrm{~h}$, because of increased duration of transport or starvation as compared with 4 and $8 \mathrm{~h}$ periods. Moreover, Montane et al. (2002) stated that increase of blood urea nitrogen in transported sheep may cause by physical exercise during transport, effect of glucocorticoids on protein catabolism and food deprivation.

Creatinine kinase became necessary variable to describe injuries and exhaustion that encountered in sheep during transport (Kent, 1997; Tadich et al., 2009; Fisher et al., 2010). Our result showed that $\mathrm{CK}$ activity continues to increasing with increasing duration of the journey. Transport for $12 \mathrm{~h}$ showed the higher CK activity than 4 and $8 \mathrm{~h}$ periods, whereas CK activity in not transport group tend to remain. Gregory (1998) indicated that increasing of CK activity as a result of physical damage encountered during handling, loading and slaughter. In addition, Fisher et al. (2010) reported that concentration of creatine kinase raised at arrival. However, increased creatine kinase in this study relatively small and was similar to the studies of Fisher et al. (2010) and Parrot et al. (1998), which transported sheep for $48 \mathrm{~h}$ and $31 \mathrm{~h}$, respectively.

\section{CONCLUSIONS}

Increasing road transportation and starvation duration for Javanese thick tailed up 4, 8 and $12 \mathrm{~h}$ resulted in reduced body weight, increased cortisol, glucose and hematocrit. However, these results are acceptable for animal well-being. This finding indicates that transported healthy Javanese thick tailed under good condition in hot-humid tropical environment up to $12 \mathrm{~h}$ can tolerate to adverse effect of transportation without disturbing their welfare. In addition, transported sheep of more than $8 \mathrm{~h}$ should be fed and watered to decrease the body weight loss. 


\section{ACKNOLEDGMENT}

This research was supported by BUDI-DN (Beasiswa Unggulan Dosen Indonesia) scholarship from Indonesian Ministry of Research, Technology and Higher Education with Contract No. No : 201710210311688

\section{REFERENCES}

Adzitey, F. 2011. Effect of pre-slaughter animal handling on carcass and meat quality. Inter. Food and Res. J. 18: 484-490.

Ali, B. H., A. A. Al-Qarawi and H. M. Mousa. 2006. Stress associated with road transportation in desert sheep and goats, and the effect of pretreatment with xylazine or sodium betaine. Res. Vet. Sci. 80 (3):343348.

Ayo, J. O and S. B. Oladele. 1996. Transport stress in food animals: A review. Nigerian. Vet. J. 1:58-68.

Broom, D. M., J. A. Goode, S . J. G. Hall, D. M. Lloyd and R. F. Parrott. 1996. Hormonal and physiological effects of a 15-hour road journey in sheep: comparison with the responses to loading, handling and penning in the absence of transport. Br. Vet. J. 152:593-604.

Cockram, M. S., J. E. Kent, R. E. Jackson, P. J. Goddard, O. M. Doherty, I. M. McGlip, A. Fox, X. Studdert-Kennedy, T. I. McConnell and T. O'Riordan. 1997. Effect of lairage during $24 \mathrm{~h}$ of transport on the behavioural and physiological responses of sheep. J. Anim. Sci. 65:391-402.

Cockram, M. S., J. E. Kent, P. J. Coddard, N. K. Waran, R. E. Jackson, I. M. McGilp, E. L. Southall, J. R. Amory, T. I. Mc-Connell, T. $\mathrm{O}^{\wedge}$ Riordan and B. S. Wilkins. 2000. Behavioural and physiological responses of sheep to $16 \mathrm{~h}$ transport and a novel environment post transport. Vet. J. 159:139146.

Caulfield, M., H. Cambridge, S. F. Foster and P. D. McGreevy. 2014. Heat stress: a major contributor to poor animal welfare associated with long-haul live export voyages. Vet. J. 199, 223-228.

Cole, N. A. 1995. Influence of a three-day feed and water deprivation period on gut fill, tissue weights, and tissue composition in mature wethers. J. Anim. Sci. 73:2548-2557.

Ekiz, B., E. Ergül Ekiz, H. Yalçıntan, A. Yılmaz,
O. Kocak and H. Güneş. 2013. Effect of ram-ewe mixed transportation on certain welfare parameters in Red Karaman and Imroz sheep. J. Fac. Vet. Med. Istanbul. Univ. 39:155-163.

European Council. 2005. Council Regulation (EC) No. 1/2005 of 2004 on the protection of animals during transport and related operations and amending Directives 64/432/EEC and 93/119/EC and Regulation (EC) No. 1255/97. Off. J. Eur.Union L3:1-44.

Fazio, E and A. Ferlazzo. 2003. Evaluation of stress during transport. Vet. Res. Comm. 27:519-524.

Fisher, A. D., D. O. Niemeyer, J. M. Lea, C. Lee, D. R. Paul and M. T. Reed. 2010. The effects of 12,30 or 48 hours of road transport on the physiological and behavioral responses of sheep. J. Anim. Sci. 88:2144-2152.

Grandin, T. 1997. Assessment of stress during handling and transport. J. Anim. Sci. 75:249257.

Gregory, N. G. 1998. Animal Welfare and Meat Science. CABI Publishing: New York.

Kent, J. E. 1997. Stress in transported sheep. Comp. Haernatol. Int. 7:163-166.

Horton, G. M. J., J. A. Baldwin, S. M. Emanuele, J. E. Wohlt and L. R. McDowell. 1996. Performance and blood chemistry in lambs following fasting and transport. J. Anim. Sci. 62:49-66.

Knowles, T. G., S. N. Brown, P.D. Warriss, A. J. Phillips, S.K. Dolan, P. Hunt, J. E. Ford, J. E. Edwards and P. E. Watkins. 1995. Effects on sheep of transport by road for up to 24 hours. Vet. Rec. 136:431-438.

Knowles, T. G., P. D. Warriss, S. N. Brown, S. C. Kestin, J.E. Edwards, A. M. Perry, P. E. Watkins and A. J. Phillips. 1996. Effects of feeding, watering and resting intervals on lambs transported by road and ferry to France. Vet. Rec. 139:335-339.

Krawczel, P. D., T. H. Friend, D. J. Caldwell, G. Archer and K. Ameiss. 2007. Effects of continuous versus intermittent transport on plasma constituents and antibody response of lambs. J. Anim. Sci. 85:468-476.

Maria, G. A., M. Villarroel, C. Sanudo, J. L. Olleta and G. Gebresenbet. 2003. Effect of transport time and ageing on aspects of beef quality. Meat. Sci. 65:1335-1340.

Minka, N. S and J. O. Ayo. 2012. Assessment of thermal load on transported goats administered with ascorbic acid during the 
hot-dry conditions. Int. J. Biometeorol. 56:333-341.

Miranda-de la Lama, G.C., P. Monge, M. Villarroel, J.L. Olleta, S. García-Belenguer and G. A. María. 2011. Effects of road type during transport on lamb welfare and meat quality in dry hot climates. Trop. Anim. Health and Prod.

Miranda - dela Lama, G.C., M.I. Salazar - Sotelo, C. Pérez - Linares, F. Figueroa - Saavedra, M. Villarroel M, C. Sañudo and G. A. María. 2012a. Effects of two transport systems on lamb welfare and meat quality. Meat. Sci. 92:554-561.

Moberg, G.P. 2000. Biological response to stress: implications for animal welfare. in the biology of animal stress (ed. GP Moberg and JA Mench), pp. 1-22. CABI Publishing, Wallingford, UK.

Montane, J., I. Marco, J. Lopez-Olvera, X. Manteca and S. Lavin. 2002. Transport stress in roe deer (Capreolus capreolus): Effect of the short acting antipsychotic. Anim. Welfare. 11:295-303.

Parrott, R. F., S. J. G. Hall, D. M. Lloyd, J. A. Goode and D. M. Broom. 1998. Effects of a maximum permissible journey time $(31 \mathrm{~h})$ on physiological responses of fleeced and shorn sheep to transport, with observations on behaviour during a short $(1 \mathrm{~h})$ rest-stop. Anim. Sci. 66:197-207.

Paull, D. R., C. Lee, S. J. Atkinson and A. D Fisher. 2008. Effects of meloxicam or tolfenamic acid administration on the pain and stress responses of Merino lambs to mulesing. Aust. Vet. J. 85:98-106.
Saeb, M., H. Baghshani, S. Nazifi and S. Saeb. 2010. Physiological response of dromedary camels to road transportation in relation to circulating levels of cortisol, thyroid hormones and some serum biochemical parameters. Trop. Anim. Health. Prod. 42:55-63.

Samimi, A. S., J. Tajik, S. M. Aghamiri and A. Karimi. 2018. A serial evaluation of electrocardiographic indices and cardiac arrhytmias during pregnancy, lactation and dry periods in Saanen goats. Bulgarian. J. Vet. Med. 21:59-66.

Silanikove, N. 2000. Effects of heat stress on the welfare of extensively managed domestic ruminants. Livest. Prod. Sci. 67:1-18.

Swanson, J. C., and T. Morrow-Tesch. 2001. Cattle transport: historical, research, and future perspective. J. Anim. Sci. 79. E102E109.

Tadich, N., C. Gallo, M. Brito and D. M. Broom DM. 2009. Effects of weaning and $48 \mathrm{~h}$ transport by road and ferry on some blood indicators of welfare in lambs. Livest. Sci. 121:132-136.

Villarroel, M., P. Barreiro, P. Kettlewell, M. Farish and M. Mitchell. 2011. Time derivatives in air temperature and enthalpy as non-invasive welfare indicators during long distance animal transport. Biosystem and Engineering. 110.253-260.

Zhong, R. Z., H.W. Liu, D. W. Zhou, H. Z. Sun and C. S. Zhao. 2011. The effects of road transportation on physiological responses and meat quality in sheep differing in age. J. Anim. Sci. 89:3742-3751. 